\title{
The Effect of Concept Mapping and Problem-Solving Teaching Strategies on Achievement in Genetics among Nigerian Secondary School Students
}

\author{
Nnamdi S. Okoye and Okechukwu, R. N. \\ Department of Science Education, Delta State University, Abraka, Nigeria
}

\begin{abstract}
The study examined the effect of concept-mapping and problem-solving teaching strategies on achievement in genetics among Nigerian Secondary School Students. The method used for the study was a quasi-experimental pre-test post-test treatment design. One hundred and thirteen senior secondary three (S.S. III) students randomly selected from three mixed secondary schools located in Delta North Senatorial District of Delta State, Nigeria were used as subjects for the study. The experimental group was taught selected topics in Genetics using concept mapping and problem-solving strategies while the control group was taught using the traditional lecture method. The result of the study showed that the experimental group performed significantly better in Genetics than the control group and that gender does not affect students' achievement in genetics.
\end{abstract}

\section{Introduction}

Scientists and science educators over the years have been focusing attention on how to improve science instruction in schools by going beyond the stereotypic methods of obtaining knowledge in science. There have been emphases in science teaching and on students' active involvement in doing science. The National Policy on education (2004) and the Biology curriculum sees biology as a practical and inquiry oriented subject that should be taught practically (involving students in the art of doing). When the students are involved in doing science, science process skills such as careful observations, classification, interpreting, predicting events, designing experiment, organizing information, reporting and generalization will be acquired.

The teacher has been found to be a very important factor in the implementation of any curriculum (Nneji, 1999; Okoye, 1999 and Umeh, 2002). Ajaja and Kpangban (2000) asserted that what the student knows or does not know depend mainly on the teacher. The Biology teacher should therefore be equipped with the right teaching strategies for effective learning to take place. Okpala (1991), Okoye 1999), Umeh (2002) Okebukola (2002), and Okechukwu (2003) have shown that both teachers and students find ecology, evolution and genetics difficult to teach and understand respectively. These difficulties may arise as a result of misconception. Yip (1998) revealed that inexperienced biology teachers hold a number of conceptual errors which are prevalent among secondary school students.

Concept maps are diagrams indicating inter-relationships among concepts as representation of meaning or educational framework specific to a domain of knowledge (Novak, 1990). Okebukola (1997) believed that the maps can be applied to any subject matter or to any level within the subject. Genetics being a somewhat difficulty aspect of biology deserve a systematic way of learning and a problem solving technique.

Most students in the senior secondary schools in Nigeria opt for biology in the senior secondary examinations. Despite the attraction this subject enjoys, students' poor achievement in Biology is alarming. Okebukola (1998) reported that between 1991 and 1995 only about $25 \%$ of the candidates presented for Biology in the Nigerian senior secondary school examination passed at credit level. However, researchers have blamed the poor state of Biology teaching and students performance on factors such as (i) lack of qualified teachers and inadequate practical work (Ali, 1998) (ii) Use of traditional teaching methods (Ollarewayju, 1986) and (iii) the highly conceptual nature of biology (Schmid and Telaro, 1990; and Umeh, 2002).

However, there is an obvious tendency that practical scientific methods such as concept mapping and problem solving is muddled up with theory during teach to the extent that the efforts distorts theoretical understanding of biological concepts. Biology teachers must consider separately the aims of each topic and 
The Effect of Concept Mapping and Problem-Solving Teaching Strategies on Achievement in Genetics among Nigerian Secondary School StudentsNnamdi S. Okoye and Okechukwu, R. N.

use appropriate method of teaching it so that students can establish a self-sufficient rationale and modus operandi for each.

It is these area of interaction between concept mapping and problem solving strategies that this study seeks to examine, to see how the two teaching strategies may help for better understanding of genetics in senior secondary schools. The implication of this to science teaching is to help students to acquire, cognitive understanding of Biological knowledge and concepts and also a mastery of the skills for their private studies in science. The study therefore seeks to examine the effect of concept mapping and problem solving strategies on achievement on genetic among secondary schools students.

\section{Research Problem}

Concept mapping and problem solving teaching strategies in science teaching are designed to help students acquire basic scientific skills and improved performance. Some science educators agree that concept mapping and problem solving promote students' achievement in science. It becomes necessary therefore to substantiate this claim empirically. The rationale for this study is to determine the effect of concept mapping and problem solving on students' academic achievement in Biology (genetics in particular). Arising from this, the following research questions were generated to guide this study:

i. Is there any significant difference in achievement between students exposed to the study of genetics using concept mapping and those exposed to the traditional lecture method?

ii. Is there any significant difference in achievement between students in achievement between students exposed to the study of genetics using the problem solving strategies and those exposed to the traditional lecture method?

iii. Is there any significant difference in the achievement among boys and girls exposed to the learning of genetics using concept mapping and problem solving teaching strategy?

\section{Research Methodology}

The study utilized a quasi-experimental pre-test, post test treatment design (Alli, 1996; Egbule, 2003). The various experimental and control groups were located in different schools consisting of male and female students and they were all of mixed ability.

The study involved one hundred and thirteen (113) senior secondary three (S.S.II) students randomly selected from three mixed secondary schools located in Delta North Senatorial District of Delta State, Nigeria.

The instrument used for data collection was the genetic Achievement Test (GAT) consisting of 40 multiple choice items and 20 short answer questions on Genetics. The reliability index of this instrument is 0.82 . Five topics on Genetics covered by the students used in this study are:

i. Transmission and expression of characters in organism and Definition of Genetic Terms;

ii. Chromosomes - the basis of heredity;

iii Variation in population;

iv. Application of principles of heredity to agriculture and medicine, and

v. Probability in genetics.

These topics are the sections in Genetics which these students were to be exposed to as contained in their S.S II and S.S III Syllabus in Biology.

These topics were taught to the experimental groups using concept mapping and problem solving teaching strategies and the control group was taught using the traditional lecture method. Those teachers who taught the three groups were specifically trained for the purpose of this study.

\section{Results}


The result of the one hundred and thirteen students from the three mixed secondary schools on the Genetic Achievement Test (GAT) was anlaysed in the tables below. In order to provide answer to the research question (i) raised above, the data collected was subjected to analysis using the analysis of convenience ANCOVA (Egbule, 2003) shown in Table 1.

Table 1 Summary table of ANCOVA in the performance of students taught genetics with concept mapping teaching strategy and traditional lecture Method (Control).

\begin{tabular}{|c|c|c|c|c|c|c|}
\hline $\begin{array}{l}\text { Source of } \\
\text { variation }\end{array}$ & $\begin{array}{c}\text { Sum of } \\
\text { squares }\end{array}$ & Df & Mean square & $\begin{array}{c}\text { Calculated } \\
\text { F }\end{array}$ & $\begin{array}{l}\text { Sig. } \\
\text { of } F\end{array}$ & Critical F \\
\hline Covariates & 1018.774 & 1 & 108.774 & 26.06 & .000 & \\
\hline Pre-test & 1018.774 & 1 & 108.774 & 26.06 & .000 & \\
\hline Main effects & 1120.260 & 1 & 1120.260 & 28.667 & .000 & \\
\hline Groups & 1120.260 & 1 & 1120.260 & *28.667 & .000 & 3.89 \\
\hline Explained & 2139.034 & 2 & 1069.517 & 27.368 & .000 & \\
\hline Residual & 2813.713 & 72 & 39.079 & & & \\
\hline Total & 4952.747 & 74 & 66.929 & & & \\
\hline
\end{tabular}

The result on the table above shows that there is a significant difference in the achievement between students taught genetics using concept mapping teaching strategy and those taught using the traditional lecture method (control). This shows that there is a significant difference between the experimental group (those taught with concept mapping strategy) and the control.

To provide answer to question (ii), the result of students exposed to problem solving strategy and those exposed to the traditional lecture method on the Genetic Achievement Test was again analyzed using ANCOVA shown in Table 2.

Table 2 ANCOVA summary table for the performance of students taught Genetics using problem solving teaching strategy and those taught with the traditional lecture method (Control).

\begin{tabular}{|l|c|c|c|c|c|c|}
\hline $\begin{array}{c}\text { Source of } \\
\text { variation }\end{array}$ & $\begin{array}{c}\text { Sum of } \\
\text { squares }\end{array}$ & Df & Mean square & $\begin{array}{c}\text { Calculated } \\
\text { F }\end{array}$ & $\begin{array}{c}\text { Sig. } \\
\text { OF F }\end{array}$ & Critical F \\
\hline Covariates & 5.371 & 1 & 5.371 & .094 & .760 & \\
\hline Pre-test & 5.371 & 1 & 5.371 & .094 & .760 & \\
\hline Main effects & 1618.893 & 1 & 1618.893 & 28.309 & .000 & \\
\hline Groups & 1615.893 & 1 & 1618.893 & $* 28.3097$ & .000 & 3.890 \\
\hline Explained & 1624.264 & 2 & 812.132 & 14.202 & .000 & \\
\hline Residual & 4117.416 & 72 & 57.186 & & & \\
\hline Total & 5741.680 & 74 & 77.590 & & & \\
\hline
\end{tabular}

*Significant: $\mathrm{P}<0.05$

The table above shows that students exposed to the problem solving strategy of teaching performed significantly better in genetics than those students exposed to the traditional lecture method of teaching. Hence, there is a significant difference in achievement between students exposed to study of genetics using problem solving strategy and those exposed to the traditional lecture method.

The attempt to provide answer to question (iii) generated for the study led to the analysis of male and female students exposed to the same methods of problem solving and concept mapping strategies. The analysis of the results obtained suing ANCOVA is hereby presented in Table 3. 
The Effect of Concept Mapping and Problem-Solving Teaching Strategies on Achievement in Genetics among Nigerian Secondary School StudentsNnamdi S. Okoye and Okechukwu, R. N.

Table 3 The ANCOVA Summary table showing the performance of male and female students taught genetics using the same method of teaching

\begin{tabular}{lcccccc}
\hline $\begin{array}{c}\text { Source of } \\
\text { variation }\end{array}$ & $\begin{array}{c}\text { Sum of } \\
\text { squares }\end{array}$ & Df & $\begin{array}{c}\text { Mean } \\
\text { square }\end{array}$ & $\begin{array}{c}\text { Calculated } \\
\text { F }\end{array}$ & $\begin{array}{c}\text { Sig. } \\
\text { of F }\end{array}$ & Critical F \\
\hline Covariates & 2704.231 & 1 & 2704.231 & 49.367 & .000 & \\
Pre-test & 2704.231 & 1 & 2704.231 & 49.367 & .000 & \\
Main effects & 2278.055 & 4 & 569.514 & 10.387 & .000 & \\
Groups & 2181.609 & 3 & 727.203 & 13.276 & .000 & \\
Sex & 40.509 & 1 & 40.509 & $* 0.740$ & .390 & 3.890 \\
2-way interaction & 112.553 & 3 & 37.518 & 0.685 & .562 & .000 \\
Explained & 5090.739 & 8 & 636.842 & 11.626 & & \\
Residual & 8873.764 & 162 & 54.776 & & & \\
Total & 13968.503 & 170 & 85.168 & & & \\
\hline
\end{tabular}

*Not Significant: $\mathrm{P}>0.05$

Table 3 shows that there is no significant difference in the performance of male and female students in genetics who are exposed to the same strategy in teaching. Hence, gender does not play any role on students academic achievement when exposed to the study of genetics using the some method.

\section{Discussions and Conclusions}

The result of this study revealed that students exposed to the concept mapping strategy while studying genetics achieved significantly higher than those students exposed to the traditional lecture method. This implies that concept mapping when incorporated into teaching, improve the students' performance in genetics. It is in line with the findings of Ige (1998); Okebakola (1997 and 1998); Osisioma (1996); and Wandersee (1990).

Using the problem-solving strategy improved significantly the achievement of students in genetics more than the students exposed to the traditional lecture method of teaching. This can be attributed to the fact that problem solving strategy equips students with both conceptual scientific knowledge and procedural knowledge on how to solve problems. This agreed with the views of Okebakola (1992), Ikitde (1993) and Okeke (2000) that problem solving teaching strategy improves performance. Ige (1998) corroborated this view in his finding that the use of problem solving techniques in the teaching of Ecology improves students' performance.

Analysis of result got from this study shows that gender does not play any role in students academic achievement when exposed to the study of genetics using the same method of teaching. This is an interesting finding and agreed with those of Daramola (1983) and Afenike (1982) Okebukola (1992) agreed with the above finding by stating that sex does not seem to account for variance in Biology achievement. Jegede et al (1990) agreed that the use of teaching strategies like concept, mapping and problem solving improves achievement and brings about a reduction of anxiety in learning for both male and female students.

The findings of Okebukola (1992) that gender difference in science achievement favoured boys over girls and that of Ikitde (1993) recording higher achievement for girls in Biology however shows that the concept of gender and science achievement (especially in Biology) is still not fully established.

Giving students more opportunity to get involved in the learning process using concept mapping and problem solving strategies make them to perform significantly better than their counterparts exposed to the teaching of genetics using the usual traditional lecture method of teaching. This study has helped to identify one of the problems of poor academic achievement for students in Biology especially genetics. The study 
goes to show that if teachers can be effectively trained in the way of scientific methods in science classrooms, they can deliver and improve the standard of science education in Nigeria.

\section{References}

Afenike, O.A. (1982). Evaluation of Chemistry Teaching in Benin City, Journal of Science Teachers Association of Nigeria Vol. 20, No. 2, 73-74.

Ajaja, O.P. and Kpangban, E. (2000). Enriching Biology Teaching in the $21^{\text {st }}$ Century in Nigeria: Implications for the teacher. $41^{\text {st }}$ Conference_Proceedings of STAN, 130-140.

Alli, A. (1996) Fundamentals of Research in Education, Awka, MEKS Publishers (Nig).

Alli, A. (1998). Strategic Issues and Trends in Science Education in Africa, Onitsha, Cape Publishers Int. Ltd.

Daramola, S.O. (1983). The Influence of Location and Sex Difference on the Knowledge of Basic Physical possessed by entering form III students in Kwara State Secondary Schools. Journal of Science Teachers Association of Nigeria, Vol. 20, No. 2, 106-112.

Egbule, J.F. (2003) Statistics for Researchers in the Behavioural Sciences and Education Owerri - Nigeria, White and White Publishers.

Federal Republic of Nigeria (2004) National Policy on Education4th Edition, Federal Ministry of Education Lagos $_{2}$ NERDC Press.

Ige, T.A. (1998). Problem Solving: Available Tool for Teaching Ecological Concepts. Proceedings of the $39^{\text {th }}$ Annual Conference of STAN, 133-136.

Ikitde, G.A. (1993). Fostering Experimental Proficiency of Students in Biology through Problem solving approach, Unpublished Ph.D Thesis, University of Ibadan, Ibadan - Nigeria.

Jegede, O.J., Alaiyemou, F.F. and Okebukola, P.A.O (1990); The Effect of Concept Mapping on Students Anxiety and achievement in Biology. Journal of Research in Science Teaching, Vol. 27 No. 10, 951-960.

Nneji, N.G. (1998). Students, Teachers and Examiners Perceptions of Difficult topics in Applied Electricity and Factors responsible for the difficulty levels. Journal of Science Teachers Association of Nigeria, Vol. 33, Nos. 1\&2, 56-61.

Novak, J.D. (1990) Concept-Mapping, a useful tool for Science Education Journal of Research in Science Teaching, Vol. 7, No. 10 937-949.

Okebukola, P.A.O (1990) Attaining Meaningful learning of concepts Genetics and Ecology. A Test of the Efficacy of the concept - mapping heuristic. Journal of Research in Science Teaching, vol. 27, No. 5, 493-504,

Okebukola, P.A.O (1992). "Can good Concept - mappers be good problem-solvers in Science"? Journal of educational Psychology, Vol. 12, No.2 113-129.

Okebukola, P.A.O (1998). Concept Maps as Instructional Tools for promoting meaningful learning in Biology. In Ajewole, et al (Eds.) Instructional Strategies for Teaching and Learning Biology in Secondary Schools", 11-25. 
The Effect of Concept Mapping and Problem-Solving Teaching Strategies on Achievement in Genetics among Nigerian Secondary School StudentsNnamdi S. Okoye and Okechukwu, R. N.

Okebukola, P.A.O (2002) Beyond the Stereotype to New Trajectories in Science Teaching, Abuja, Trade and Style Publishers.

Okechukwu, R.N. (2003), Isolating Topics of highly perceived difficulty in Senior Secondary School Biology Curriculum. An unpublished Ph.D. Seminar, Delta State University, Abraka.

Okeke, C.E. (2001). Grassroots Promotion of Basic Science in Nigeria. A paper presented at the $3^{\text {rd }}$ Prof. K. O. Dike memorial lecture by the Nigerian Academy of Science, Nnamdi Azikiwe University, Awka Anambra State, Nigeria.

Okoye, N.S. (1998). Family structure and Achievement in Biology among Secondary School Students in Delta state, Nigeria, Journal of CITADEL, vol. 3, No.6, 98-108.

Okoye, N.S. (1999). Biology laboratory Facilities as tools in the Teaching and learning of Biology in secondary schools, Knowledge Review, vol. 1 No. 2, 60-66.

Okpala, J.O. (1991). Teaching Genetics in Senior Secondary schools approach expected teacher competencies and constraints. Journal of Science Teachers Association of Nigeria, Vol. 2, No. 1, 23-28.

Olariwaju, A.O. 91986). Students under achievement in Science and Some remedies. Proceedings of $27^{\text {th }}$ Edition of STAN, 143-147.

Osisioma, U.I. (1990). Effects of mode of Concept Mapping and Gender on students achievement in and attitude towards integrated science. Unpublished Ph. D. Thesis, University of Nigeria, Nsukka

Schmid, R.F. and Telaro, G. (1990). Concept mapping as an instructional strategy for high school Biology. Journal of Educational Research, vol. 54, No. 2 78-85.

Umeh, M.O. (2002). Reducing Teachers Instructional Difficulties on some content areas in senior secondary Biology Curriculum for Sustainable development. Proceedings of the $43^{\text {rd }}$ Annual Conference of STAN, 219-223.

Wandersee, J.A. (1990). Concept Mapping and Cartography of Cognition. Journal of Research in Science Teaching, Vol. 27, No. 10, 923-936.

Yip, D.Y. (1998). Identification of Misconception on Novice Biology Teachers and Remedial Strategies. International Journal of Science Education, Vol. 20, No.4, 461-477. 